\title{
The social exclusion discourse: ideas and policy change
}

\section{Daniel Béland}

\section{English}

This article explores the political discourse of social exclusion and its potential impact on social policy. The analysis suggests that in France, Britain, and the European Union at large, the growing political focus on social exclusion has helped to shift policy attention away from other forms of inequality, including income inequality. This logic and the reforms enacted in the name of social inclusion are compatible with moderate forms of economic liberalism distinct from Thatcherite neoliberalism. Theoretically, the article draws on the social science literature on the role of ideas to stress the possible consequences of the social exclusion discourse.

\section{Français}

Cet article étudie le discours politique de l'exclusion sociale et son impact potentiel sur la protection sociale. L'analyse suggère qu'en France, en Grande Bretagne et dans l'Union européenne en général, l'accent politique grandissant sur l'exclusion sociale a contribué à éloigner l'attention politique d'autres formes d'inégalité, y compris les inégalités de revenus. Cette logique et les réformes adoptées au nom de l'exclusion sociale sont compatibles avec des formes de libéralisme économique différentes du néolibéralisme thatchérien. Théoriquement, l'article s'appuie sur les travaux de science sociale traitant du rôle des idées pour mettre l'accent sur les conséquences possibles du discours sur l'exclusion sociale.

\section{Español}

Este artículo explora el discurso político de exclusión social y su impacto potencial en la política social. El análisis sugiere que en Francia, Gran Bretaña y la extensa Unión Europea, el creciente foco político en exclusión social ha ayudado a cambiar la atención política lejos de otras formas de desigualdad, incluyendo ingresos desiguales. Esta lógica y las reformas promulgadas en nombre de inclusión social son compatibles con formas moderadas de liberalismo económico distinto del neoliberalismo Thatcherite. En teoría, el artículo se basa en los estudios de ciencias sociales en cuanto al papel de ideas para enfatizar las posibles consecuencias del discurso de exclusión social. 


\section{Introduction}

Since the election of the first Blair government, the issue of social exclusion has become a major aspect of British social policy debates (Levitas, 2005). This issue has also gained much ground at the European Union level (Silver and Miller, 2003). Yet social exclusion is a contentious issue and scholars have debated the usefulness of this concept (eg Blanc, 1998). ${ }^{1}$ Because the concept of social exclusion first emerged in France and has long been a major policy issue there, it is appropriate to use France as the starting point for an inquiry into the meaning of that concept (eg Silver, 1994). The objective of this article is to draw extensively on the French case to shed new light on the political discourse about social exclusion and its potential impact on welfare state restructuring. Such an analysis suggests that the current political focus on social exclusion has helped to shift policy attention away from other forms of inequality, including income inequality between the wealthy and the rest of the population. This logic, as well as the content of many reforms enacted in the name of social inclusion (ie the fight against social exclusion and for citizenship integration), is compatible with moderate forms of economic liberalism distinct from Thatcherite neoliberalism. This fact partly explains the success of the concept of social exclusion among centre-left and Third Way politicians and public intellectuals, both in France and in Britain. The argument here is not that the struggle against social exclusion can only take a liberal meaning, or that this concept should be discarded altogether. Indeed, the concept of social exclusion can take different meanings (Silver, 1994; Levitas, 2005), and it has the potential advantage of emphasising social problems that do not fall under the traditional concept of poverty. For example, this concept stresses the logic of 'cumulative disadvantage' that affects the most deprived segments of the population (Silver and Miller, 2003). But, as mobilised in centre-left and Third Way political discourse, the idea of social exclusion can become a powerful ideological tool that legitimises modest policy reforms entirely compatible with moderate understandings of economic liberalism and, ultimately, unable to fight the social evils this idea refers to. Theoretically, the article draws on the growing literature on the role of ideas in policy making to underline the three main ways in which the political discourse on social exclusion can impact policy making and welfare state reform (ie serving as policy paradigm, reform blueprint, and justification device).

Three main sections comprise this article. First, a brief discussion about the role of ideas and discourse provides the necessary theoretical background to understanding the potential impact of the social exclusion discourse on welfare state reform. Second, an extended discussion of the French case traces the history of the concept of social exclusion before analysing the political discourse and the concrete social measures that have surrounded it since the late 1980s. Finally, a more concise section explores the similarities and the differences between the French and the British cases regarding the policy and ideological consequences of the social exclusion discourse. Because there is a lot of excellent scholarship already available about the British case (eg Levitas, 2005), this final section does not need to offer a comprehensive analysis of Third Way social policy but, instead, only comparative insight about the social exclusion discourse derived from the analysis of the French case. 


\section{The idea of social exclusion and policy making}

Ideas impact political decisions in three main ways (Blyth, 2001, 2002). ${ }^{2}$ First, ideas can serve as 'cognitive locks' that help reproduce existing institutions and policies over time. This role of ideas corresponds to Peter Hall's widely cited work of policy paradigms and degrees of institutional change. For Hall, a policy paradigm is 'a framework of ideas and standards that specifies not only the goals of policy and kind of instruments that can be used to attain them, but also the very nature of the problems they are meant to be addressing' (Hall, 1993: 279) Second, ideas serve as policy blueprints that provide political actors with a model for reform. Offering a basic understanding of actors' interests, institutional opportunities and the economic pressures at stake, this model helps actors coordinate their efforts and build coalitions around common economic, social and political objectives. Third, ideas constitute powerful ideological weapons that 'allow agents to challenge existing institutional arrangements and the patterns of distribution that they enshrine' (Blyth, 2001: 4) These ideas constitute a political discourse that, through framing processes (Campbell, 1998; Schmidt, 2001; Fischer, 2003), seek to convince decision makers, interest groups and the population at large that change is necessary. This is what Robert Cox labels 'the social construction of the need to reform'. 'In a political environment the advocates of reform need to employ strategies to overcome the scepticism of others and persuade them of the importance of reform. In other words, they must create a frame that changes the collective understanding of the welfare state, because doing so 'shapes the path' necessary to enact reform' (Cox, 2001: 475).

Following this typology, the idea of social exclusion can contribute to three political tasks in the field of social policy reform. First, social exclusion constitutes a specific form of understanding that participates in the construction of both social problems and the policy responses to them. From this perspective, the concept of social exclusion helps experts and policy makers make sense of the social world and design policies aimed at solving the social problems they deem important. But any policy paradigm comes with specific intellectual 'blind spots', as the focus on certain social problems relegates others to the periphery of the policy agenda. Second, this idea, and the related concept of social inclusion, can become the centrepiece of reform blueprints. This is especially true when social exclusion is tied to powerful concepts like solidarity and social citizenship. Centre-left and Third Way governments seeking to preserve references to social justice and national solidarity in the context of economic liberalism are especially prone to embrace a high-profile, yet ultimately modest, campaign against social exclusion. The politics of social policy reform under the Rocard government in France and the Blair governments in Britain provides ground to this claim. Finally, the discourse about social exclusion and inclusion can become an effective framing tool to justify the 'need to reform' and promote specific policy alternatives. As suggested above, the explicit quest for social inclusion and 'national solidarity' in France legitimised the enactment of social programmes that reduced the fiscal reliance on social insurance contributions, which is one of the core policy imperatives of contemporary economic liberalism in continental Europe. ${ }^{3}$ In Britain, an increasingly moralistic social exclusion discourse constructed the need for workfare, a policy idea 'imported' from the US during the Clinton years (Daguerre, 2004). 
The following section on France will first trace the emergence of the social exclusion paradigm before analysing the formulation of an exclusion-centred reform blueprint and, finally, the framing of a justification discourse about social exclusion that participates in the construction of the 'need to reform' the French welfare state.

\section{Social exclusion and social policy reform in France}

As it emerged after the Second World War, the modern French welfare state was embedded in a social insurance model that prominently featured 'occupational solidarity' (solidarité professionnelle). This means that, despite efforts to unite existing pre-war social insurance schemes, the French welfare state has largely remained fragmented among occupational lines. In addition to the régime général protecting private sector workers, dozens of autonomous insurance schemes cover about $20 \%$ of the workforce (eg Béland and Hansen, 2000). Occupational categories participating in these schemes include independent workers, farmers and civil servants. Despite this high level of fragmentation, the post-war French social insurance system offered earnings-related benefits to the vast majority of the working population. Furthermore, employers and labour unions participated in the administration of the social insurance system. Yet, with the exception of unemployment insurance, the French state maintained a central role in the governance of this system. Although that system represented the centrepiece of the welfare state, social assistance programmes granting genuine social rights existed to help those excluded from the labour market (Bec, 1998).

\section{The emergence of the social exclusion paradigm}

In France, as in most other advanced industrial countries, the expansion of the post-war welfare state coincided with almost three decades of economic prosperity that ended with the 1973 oil crisis and the following stagflation era. It was during the last of these three decades of prosperity that the term 'exclusion' emerged in the French social and academic discourse. ${ }^{4}$ As early as 1965 , social commentator Jean Klanfer published a book entitled L'Exclusion sociale: Étude de la marginalité dans les sociétés occidentales [Social exclusion: The study of marginality in western societies]. In this moralistic book emphasising personal responsibility, the term 'social exclusion' refers to people who cannot enjoy the positive consequences of economic progress due to irresponsible behaviour (Klanfer, 1965). Less than a decade later, René Lenoir published Les exclus: Un français sur dix [The excluded: One Frenchman out of ten]. For Lenoir, the excluded are those citizens who are separated from mainstream society because of factors like disability, mental illness and poverty. According to Lenoir who, as a civil servant, had studied French social problems for more than 15 years, as much as $10 \%$ of the population suffered from social exclusion. Focusing on social and economic conditions rather than personal responsibility to explain social problems, Lenoir thus defines social exclusion in an extremely broad manner (Lenoir, 1974). Although the meaning of the term 
'exclusion' has changed since the mid-1970s, Lenoir's book is widely regarded as the 'founding document' of the modern discourse about exclusion in French society (Frétigné, 1999: 63).

During the 1980s and 1990s, the prevalence of long-term unemployment and growing concerns about racism and discrimination altered the meaning of social exclusion, a concept that increasingly - yet not exclusively - defined the lack of social integration related to limited access to labour market opportunities. From the perspective of the emerging social exclusion paradigm, long-term unemployment is a major source of social isolation. This is why social exclusion constitutes a threat to France's Republican model of integration based on the ideas of citizenship and social solidarity. Although evidence suggests that there is no strong relationship between unemployment and social isolation (Gallie et al,2003), the belief that long-term unemployment and, consequently, social exclusion represent a major threat to social order is featured prominently in the discourse about the deprived suburbs of France. To a certain extent, the geographical isolation of these suburbs reinforces the idea that France was witnessing the advent of a divided society that betrayed the egalitarian model of citizenship and social integration at the centre of the French republican tradition. 'The very word la banlieue, which creates an image of crime and indigence, graffiti and burned-down cars cut off from Paris and other French cities highlights the extent to which the extreme deprivation of segments of French society is marginal to the majority's daily existence and life chances' (Béland and Hansen, 2000: 54). Economic and urban problems bred ethnic tensions as a portion of the population of African descent felt increasingly left behind. The emergence of the racist Front National in the mid-1980s exacerbated such tensions. This situation triggered a debate over the efficiency of the 'French model of integration' based on secularism and colourblind public policy (Schnapper, 1998). Furthermore, although the excluded were generally described as the victims of unfavourable economic and social conditions, the growing discourse about 'urban insecurity' suggested that those excluded from mainstream society could become a menace to ordinary citizens, and even to the Republican order as a whole. The suburban riots of October and November 2005, France's 'worst unrest since the student uprisings of 1968', exacerbated fears of 'urban violence' and led Prime Minister Dominique de Villepin to declare a state of emergency (Associated Press, 2005).

At the cognitive and paradigmatic level, there are two original things that distinguish the term 'social exclusion' from other concepts used to define contemporary social problems. First, this term has a strong biographical meaning because it refers to the personal experience of social and economic isolation supposedly related to unemployment, discrimination and other social problems (Goguel d'Allondans, 2003: 43). Second, social exclusion is based on a horizontal, spatial metaphor rather than a vertical model of inequality focusing mainly on income disparities. From the perspective of the social exclusion paradigm, people are more 'in' or 'out' of mainstream society than 'up' or down' the class or the income distribution structure. Because of that, it is possible to argue that, in France, the growing emphasis on social exclusion during the 1980s and 1990s helped move the social and political debate away from class inequality and income redistribution at large (eg Friot, 1998). When long-term unemployment and social 
isolation become the centre of attention, class and income inequality increasingly moves to the outskirts of the policy agenda. ${ }^{5}$ From this perspective, the focus on social exclusion is compatible with moderate interpretations of economic liberalism, which are grounded in the assumption that the state should fight deprivation but not income inequality at large, a phenomenon described as a condition of economic prosperity. Furthermore, in France as elsewhere, the struggle against long-term unemployment and social exclusion has mainly favoured the enactment of fiscally modest measures financed through general revenues of the state, not payroll taxes. This is important for two reasons: first, comparatively high payroll taxes, like the ones existing in France, are perceived as an obstacle to economic competitiveness in the era of economic globalisation and European integration; second, and consequently, social policy reforms enacted in France since the late 1980s have attempted to reduce the relative role of payroll taxes within the French welfare state in part by referring to a great patriotic struggle against social exclusion (Béland and Hansen, 2000; Palier, 2002; Barbier and Théret, 2004).

Before exploring the social exclusion blueprint and the welfare reforms stemming from it, one can formulate a few cautionary remarks about the impact of economic liberalism in France. As opposed to countries like Britain and the US, explicitly neoliberal political discourse against the welfare state is hardly popular in France, where Thatcherite reforms are viewed with suspicion. And, when blatantly neoliberal reforms are pushed forward, waves of protest like the strikes of December 1995 can put those in power into a difficult situation (eg Béland and Hansen, 2000). Furthermore, post-war economic legacies make Thatcherite neoliberalism impossible to implement in France. This means that, in this country, the triumph of economic liberalism during the 1980s took a more moderate form than in Britain and the US, for example (Prasad, 2005). ${ }^{6}$ Finally, as underlined below, the moralistic side of Thatcherite neoliberalism grounded in the idea of workfare enjoys little political support in France. These cautionary remarks are crucial to understand the ideological background of France's policies dealing with social exclusion.

\section{The social exclusion blueprint and policy change}

It was only in the late 1980s and early 1990s that the idea of 'exclusion' became a central political issue in France. From this perspective, references to social exclusion and inclusion emerged as a coherent blueprint for social policy reform. Two factors helped transform the fight against social exclusion into a policy blueprint capable of guiding policy change. First, the increase of long-term unemployment and the growing public debate about racism in French society pushed this issue onto the policy agenda. Second, political actors began to identify themselves with the struggle against social exclusion in an era of fiscal austerity and economic deception. In a macro-economic context that had witnessed a shift from Keynesianism to a moderate form of economic liberalism during François Mitterrand's first presidential mandate (Jobert, 1994; Schmidt, 1996), elected officials, especially those on the left, found in the struggle against exclusion a vehicle to reaffirm their strong commitment to the ever popular Republican model of integration while showing their generosity towards the unemployed. Politically, the Rocard years (1988-91) represented a 
turning point in French social policy development as the Socialist government attempted to significantly restructure the welfare state in a manner compatible with both the liberal economic paradigm and the Republican social solidarity imperative that one can trace back to the work of Émile Durkheim and his followers (Bourgeois, 1998; Humphreys, 1999). Retrospectively, one could argue that the Rocard government attempted to articulate a new centre-left policy blueprint and agenda compatible with moderate forms of economic liberalism. ${ }^{7}$ Two crucial measures were adopted under the Rocard government: the Revenu minimum d'insertion (RMI) [Minimum Integration Income] and the Contribution sociale généralisée (CSG) [Universal Social Contribution]. Favouring a partial shift from social insurance and 'occupational solidarity' to universal social assistance rights and 'national solidarity', these measures would have a long-term impact on the French welfare state (Palier, 2002; Barbier and Théret, 2004).

Unanimously adopted by the National Assembly in December 1988, the RMI is a social assistance programme that provides modest financial support to unemployed individuals aged 25 and older who have exhausted their unemployment insurance benefits. ${ }^{8}$ Grounded in the Republican idea of 'national solidarity', this programme therefore assumes that 'family solidarity' (ie parental help) would provide minimum support to the unemployed aged between 18 and 24. Yet the RMI defines social assistance as a right of citizenship - at least for those older than 24. More importantly, the RMI is not defined as a traditional, 'passive' form of assistance but as an 'active' one. This means that one of the main objectives of the RMI is to help those who face long-term unemployment to reintegrate into the labour market. While rejecting the punitive concept of workfare which was then becoming more popular in the US, French policy makers promoted the concept of insertion, which is featured in the programme's very name (Barbier and Théret, 2001). In the French social and political discourse, insertion refers to a participatory model of 'activation' based on a contractual model rather than the punitive logic that later triumphed in the US with the enactment of the controversial 1996 welfare reform (Personal Responsibility and Work Opportunity Reconciliation Act). This provides more ground to the idea that France's policy makers have rejected the moralistic and neoliberal logic of workfare that became dominant in the US and, later, in Britain (Morel, 2000; Daguerre, 2004). Within the French Republican model, the state has the obligation to provide assistance to citizens (Bec, 1998). Yet what the RMI introduces is a contrat d'insertion that creates a sense of reciprocal obligations between the state and the beneficiary. Such a contract enumerates the tasks the beneficiary should undertake in order to reintegrate the labour market (eg returning to school, undertaking occupational training). Although this contract is more symbolic than constraining, it lays the foundation for a more individualised form of social protection and economic integration (Rosanvallon, 2000). In this context, the role of the state is not only to provide minimum financial support but to help the long-term unemployed return to the labour market. In contrast with the optimistic rhetoric about insertion surrounding the enactment of the RMI in 1988, this programme has been criticised for its modest benefits and limited success regarding the actual proportion of beneficiaries who find a permanent job after spending months or even years on welfare. From this perspective, the RMI does not strongly reduce economic insecurity as a large proportion of beneficiaries spend their time moving 
in and out of the labour market between precarious, short-term contracts and 'passive' assistance (Bec, 1998). ${ }^{9}$

A second major social policy measure passed during the Rocard years is the Contribution Sociale Généralisée (CSG). Enacted in 1991, the CSG is the first among a series of policies that have favoured a partial shift from contributionfinancing to tax-financing in the French welfare state. Initially, the CSG proved relatively modest, with a tax rate of $1.1 \%$ levied on all incomes. Over the years, however, successive governments have increased that rate (Levy, 1999; Palier, 2002), which, in 2005, varied between 3.8 and 8.2\% (French Government, 2005). One of the rationales of the CSG is to limit the level of social insurance contributions that, from the perspective of economic liberalism, are perceived as a strong obstacle to job creation and, consequently, the fight against long-term unemployment (Jobert, 1994). In order to promote job creation and reduce social exclusion, the French government has thus offered targeted reductions in social insurance contributions affecting low-paid workers.

It was during the 1990s that social exclusion, both as a policy blueprint and a political discourse, became truly dominant in France. Considering the neoliberal context of fiscal austerity related to European monetary integration and global competitiveness, however, successive French governments could hardly launch bold social programmes to fight social exclusion and long-term unemployment. Perhaps because of that, the social inclusion blueprint essentially led to the enactment of symbolic measures like the Loi d'orientation de lutte contre les exclusions [Guidelines for the Struggle against Social Exclusions] of May 1998. Marginal in its concrete policy effects, this legislation appeared as a mere political statement of the Socialist Jospin government (1997-2002) regarding its commitment to fight all forms of social exclusion and to help needy citizens. Yet this commitment led to a few significant measures, like the 1999 legislation that made health coverage truly universal for the first time. Following the adoption of this measure, the French state provided health coverage to deprived individuals who were not participating in existing social insurance schemes. Although modest, this measure constitutes a highly symbolic legislation adopted in order to fight social exclusion.

\section{The social exclusion discourse and the construction of the 'need to reform'}

In France, as elsewhere, social exclusion is not only a term that refers to a set of social and economic problems; it also constitutes a powerful political and normative discourse about the welfare state and the reforms necessary to adapt it to changing social and economic conditions. For this reason, the discourse on social exclusion participates in the 'social construction of the need to reform' (Cox, 2001) and can legitimise path-departing reforms in the name of 'national solidarity' and social citizenship (Béland and Hansen, 2000). Yet, because these reforms reduce the role of social insurance schemes and focus mainly on the 'truly needy' at the expense of other forms of inequality, they are compatible with neoliberal assumptions about economic and social regulation. Seldom criticised directly, such discourse on social exclusion has become dominant in mainstream French political circles, especially with the Socialist Party. During the 1990s, the struggle against social exclusion 
became one of the most central aspects of the Socialist Party's centre-left platform (eg Jospin, 1998). ${ }^{10}$ Still, moderate right-wing politicians like Jacques Chirac have also embraced the struggle against exclusion, for example during the 1995 presidential campaign, making it the central element of his electoral platform for a strategic reason (ie the need to seduce moderate and Socialist voters). A few months after his election to the presidency, he made sure to remind the public about his commitment to fight social exclusion (Chirac, 1995). Although an example of political opportunism that faded away after the 1995 presidential election, this discourse suggests that, during the 1990s at least, one witnessed a convergence of both the moderate left and the moderate right around the issue of social exclusion. A moral issue surrounded by references to the Republican tradition, the war on exclusion represented a fiscally affordable yet highly symbolic (Republican) form of social policy restructuring.

Beyond the political field, centre-left public intellectuals depicted the war on social exclusion as a major objective of French public policy that would mean the end of the traditional social insurance model that had dominated France's social policy arena since the beginning of the 20th century. The most prominent of these public intellectuals is probably Pierre Rosanvallon, a scholar who has been associated with the Socialist Party and the centrist labour union CFDT (Confédération Française Démocratique du Travail). In his 1995 best-seller La nouvelle question sociale: Repenser l'état-providence [translated in 2000 as The new social question: Rethinking the welfare state], Rosanvallon offers a theoretical and ideological justification for the reforms enacted under the Rocard government (CSG, RMI). Furthermore, this author argues that more reforms are needed in order to adequately fight social exclusion and long-term unemployment while pushing the French welfare state further away from the traditional social insurance model. According to him, the 'passive welfare state' should become less central as the 'active welfare state' emerges as a new tool of social integration and insertion. For Rosanvallon, the social insurance model implemented decades ago is less and less consistent with the new structure of risk that characterises contemporary society. Among the new social risks, social exclusion is certainly the most crucial one. In part because of that, the RMI is described as a model for future social programmes, whose goal would be to promote active economic citizenship. As for the CSG, it is depicted as an innovative fiscal model that could bring about genuine 'national solidarity' while moving beyond the fiscally regressive aspect (and the economic burden) of social insurance contributions (Rosanvallon, 2000). In the name of inclusion and social citizenship, Rosanvallon is advocating path-departing reforms that would reduce the relative weight of social insurance. Although this project remains largely unfinished, his ideas show how concerns about social exclusion can help construct the need to restructure social insurance schemes compatible with economic liberalism. ${ }^{11}$

In France, such a frontal ideological attack against social insurance provoked a strong reaction from the far left, especially from supporters of 'old left' labour unions like FO (Force Ouvrière) and the CGT (Confédération Générale du Travail). Interestingly, these unions seldom address the issue of social exclusion, perhaps because it may underline the limits of the social insurance model with which they identify. This is true because labour unions participate in the management of the French social insurance system, and this participation provides them with significant 
material and symbolic benefits (eg Bonoli, 2000). Opinion polls also suggest that the public support the maintenance of business and labour participation in social insurance governance. Furthermore, elected officials rarely attack the idea of social insurance publicly, as they fear negative reactions from social partners (Clasen and Clegg, 2003: 372-3). Finally, on the far left, public intellectuals like Bernard Friot oppose the discourse on social exclusion and 'national solidarity'. According to Friot, the CSG and the struggle against social exclusion constitute an attack against the protected wage system based on social insurance principles and the traditional class distinction between workers and employers. Consequently, this author explicitly opposes British-style, universalistic welfare to 'occupational solidarity' based on class relations (Friot, 1998).

Overall, this section showed that, in France, social exclusion gradually became an influential paradigm in the 1970s and 1980s, before emerging in the early 1990 s as a centre-left reform blueprint and a political discourse participating in the 'social construction of the need to reform' (Cox, 2001) post-war policy legacies.

\section{From France to Britain}

Social exclusion as a paradigm, a blueprint and a political discourse has been dispersed throughout Europe and beyond. This diffusion process began in the mid-1980s, when Jacques Delors, then president of the European Commission, stressed the need for a strong 'social dimension' to the European project. From this perspective, the fight against social exclusion gradually became a European policy paradigm and justification discourse. Following this logic, during the 1990s, 'the third EU “poverty programme" was gradually transformed into a fight against social exclusion' (Silver and Miller, 2003: 5). The 2000 Lisbon and Nice European Councils reinforced this commitment in the struggle against exclusion, which had gradually become a major feature of the European blueprint about social welfare, especially employment policy (eg Begg and Berghman, 2002; van Berkel and Hornemann Møller, 2002). The fight against exclusion is now a major aspect of the so-called 'open method of coordination', and the European Union and other European organisations have published numerous reports and studies about social exclusion (eg Fernández de la Hoz, 2001).

Although the transmission of the idea of social exclusion throughout Europe came to the attention of some British policy makers, it was the advent of the Third Way and, more specifically, the 1997 electoral victory of 'New Labour' that pushed the issue of social exclusion into the centre of the policy agenda. The first symbol of this new focus was the Social Exclusion Unit (SEU), an organisation created in December 1997. Less than three years later, Melissa Benn could even write that 'To many government insiders, the SEU is the jewel in Labour's policy crown, its favoured administrative son' (Benn, 2000: 309). In his various speeches, the Prime Minister emphasised the need for an ambitious social inclusion blueprint: 'I have always said that turning the tide of social exclusion is a ten-year project. We have made a start but there are still far too many areas where people have no job, no shop, no bank account, no links to the mainstream economy. Bringing people into the economy and giving them access to the opportunities that others take for 
granted requires us to make a new connection between economic opportunity and social renewal' (Blair, 1999). Yet, as Benn points out, the gap between the Prime Minister's blueprint and the actual measures enacted 'in the name of inclusion' - for example the various 'New Deals' - is striking (Benn, 2000). Regarding the social exclusion blueprint, this is certainly something that the French and the British situations have in common: powerful rhetoric about social justice yet modest resources allocated to social inclusion programmes. This remark points to another striking similarity between France, Britain and the European Union at large: the compatibility between some forms of economic liberalism and the social exclusion paradigm that provides the intellectual and ideological background for centrist policy making. In the case of New Labour, its Third Way approach to social and economic problems is grounded in the explicit recognition that the new government should preserve most of Thatcher's economic and social policy legacy (Hefferman, 2000: 65). Like in France, the official, centrist discourse about social exclusion helps to shift the policy attention away from broad forms of income inequality, particularly the one between the wealthy and the rest of the population. This is true in part because the Third Way's agenda is rooted in the assumption that the citizen's capacity to participate in social and economic life is a better measure 'of social justice than income inequality alone' (Davies, 2005: 13). The recent work of Anthony Giddens provides an ideological justification to that paradigm shift (Giddens, 2001). Concretely, income inequality is increasing in Britain and 'between 1996 and 2001 Britain moved from sixth to fourth most unequal in the European Union, passing Ireland and Italy' (Davies, 2005: 22). At the social policy level, the fight against exclusion has justified the moving away from unconditional social rights to conditional entitlements related to the idea of 'activation' (Dwyer, 2004). This model of 'activation' involves the imposition of work-related conditions to entitlements, which is compatible with the transformation of social assistance witnessed in the US and in other European nations (Cox, 1998). ${ }^{12}$ Among the many British measures enacted to fight social exclusion and to bring 'activation' about are the 1999 Welfare Reform and Pensions Act, the 2002 Job Centre Plus initiative, and the various New Deals for the youth and the unemployed (Dwyer, 2004). Overall, the push for 'activation' has proved stronger in Britain than in France, where the RMI's contrat d'insertion is distinct from the workfare model the first Blair government borrowed from the Clinton administration (King, 1999; Clasen and Clegg, 2003: 366; Daguerre, 2004). From this perspective, the official New Labour discourse about social exclusion justifies conditional entitlements in the name of an increasingly moralistic vision of social inclusion (Levitas, 2005).

Although it emphasises a convergence between the French and the British social policy discourse about social exclusion, this comparison does not suggest that the situation in these two countries is identical. First, Thatcherite neoliberalism has never become prominent in France, where economic liberalism has a more moderate character than in Britain. Second, the French discourse on social exclusion is centred on the notion of social solidarity, which is not a prominent feature of the British political discourse. Third, the British discourse on 'activation' is increasingly grounded in moralistic claims about personal responsibility that are less apparent in France. In that country, it is politically risky to 'blame the victim', an approach perceived as an attack against the idea of social solidarity so central in the French Republican 
model. The late 2005 social and political backlash against the harsh and moralistic 'law and order' discourse of the French Minister of the Interior Nicolas Sarkozy provides ground to this claim (eg Ridet, 2006). Fourth, in France, social exclusion had long existed as a widely debated concept and paradigm before becoming the centrepiece of a prominent policy blueprint, which was not the case in Britain. There, the Blair government suddenly transformed it into a prominent policy blueprint and discourse before it emerged as a shared paradigm (eg Marsh, 2004: 19). In other words, as opposed to the situation prevailing in France, social exclusion became a blueprint and a justification discourse before academics, journalists and public intellectuals began to discuss its meaning seriously as a cognitive category. In such a context, it is the transformation of social exclusion into a major Third Way blueprint and discourse that forced many British academics and public intellectuals to embrace the social exclusion paradigm or, at the very least, to engage critically with it. ${ }^{13}$

\section{Conclusion}

The political debate over social exclusion is still raging in France, Britain and elsewhere in Europe, so it is perhaps too early to derive definitive conclusions about the policy impact of the political discourse on social exclusion and inclusion. Drawing extensively from the French case, this article suggests that social exclusion can become a policy paradigm, the centrepiece of influential reform blueprints and a justification discourse. From this perspective, the politics of social policy surrounding the issue of social exclusion features the three main ways in which ideas can impact policy development: the crystallisation of policy paradigms that affect the perception of social problems, the elaboration of reform blueprints and, finally, the construction of the 'need to reform' and the related justification of relevant policy options. Regarding the social exclusion debate, these three types of ideational processes helped move policy attention away from other forms of social inequality while legitimising specific policy alternatives compatible with moderate interpretations of economic liberalism and, consequently, with centre-left and Third Way agendas.

Yet, the above discussion about the French and the British cases should not suggest that social exclusion is in itself a liberal idea, or that scholars should get rid of this potentially meaningful concept altogether. Social exclusion can become a useful intellectual tool, and perhaps references to this idea could draw the public's attention towards major social problems not associated with traditional concepts such as poverty and the 'underclass' (Silver and Miller, 2003). Yet, in the current context, the dominant political discourse about social exclusion has done little more than legitimise modest social programmes that seldom challenge the liberal logic seeking to limit social spending while encouraging citizens to become increasingly dependent on market outcomes (ie 'recommodification'). ${ }^{14}$

All in all, this article points to the crucial fact that the politics of ideas involves major symbolic struggles, and scholars, although they are not always aware of it, participate in them on a regular basis. As the French and the British cases suggest, academic debates about social exclusion have a political meaning, and students of 
social policy should keep in mind that their discourse about this issue can matter a great deal.

\section{Acknowledgements}

The author would like to thank John Myles for his advice as well as Joshua Humphreys, Angela Kempf, Bruno Théret, Christopher Williams and the two anonymous referees for their comments on previous drafts of this article.

\section{Notes}

${ }^{1}$ Both in France and in Britain, scholars have criticised the concept of social exclusion (eg Paugam, 1991; Castel, 2003; Levitas, 2005).

${ }^{2}$ The following typology is grounded in analytical distinctions that are sometimes blurred in concrete political life. On the role of ideas and discourse in social policy reform, see Schmidt (2002); Béland (2005); Somers and Block (2005). For a stimulating discussion about the political impact of ideas, see Hansen and King (2001).

${ }^{3}$ Economic liberalism promotes free trade and economic competitiveness related to a push for lower taxes and greater labour market flexibility. Dominant political interpretations of this economic paradigm vary from one country to another. Thatcherite neoliberalism is a radical and explicitly anti-welfare form of economic liberalism.

${ }^{4}$ On the history of the idea of exclusion in France, see Silver (1994); Paugam (1996); Goguel d'Allondans (2003).

${ }^{5}$ On the idea that the discourse on social exclusion is related to a decline of concerns about income inequality at large, especially the one between middle and upper class, see Hills (2004).

${ }^{6}$ For a comparison between the French and the British discourse on economic adjustment, see Schmidt (2001).

${ }^{7}$ The centrist mood prevailing at the time within the moderate left is reflected in a book published in 1988 by three major French public intellectuals: Furet, Julliard and Rosanvallon (1988).

${ }^{8}$ In 2004, RMI spending reached 5.7 million euros. Yet, considering that French 'social spending' (including healthcare, unemployment insurance and pensions) was as high as 480 billion euros, the RMI is definitely a modest measure, at least from a fiscal perspective (DRESS, 2005).

${ }^{9}$ In February 2000, for example, more than 30\% of RMI beneficiaries had a job. Yet, two thirds of these jobs were temporary ones, not long-term contracts (DRESS, 2002). 
${ }^{10}$ It is worth noting that the idea of the Third Way has never become popular in France, and that Prime Minister Jospin explicitly distanced himself from such an idea during his time in office. This is why one can only refer to the Socialist Party as a centre-left organisation, not a Third Way one.

${ }^{11}$ Rosanvallon is not embracing Thatcher-style liberalism but simply suggests offsetting the negative consequences of economic liberalism with a dose of social solidarity.

${ }^{12}$ For a broad discussion concerning the status of activation in the contemporary debate over social policy restructuring, see Jenson and Saint-Martin (2006).

${ }^{13}$ This does not mean that, in France, scholars working on social policy issues never feel obliged to refer to what has become an unavoidable policy (and political) issue in France (Blanc, 1998).

${ }^{14}$ The concept of 'recommodification' is borrowed from Gilbert (2002).

\section{References}

Associated Press (2005) 'France declares state of emergency', New York Times, 9 November.

Barbier,J.-C. and Théret, B. (2001) 'Welfare to work or work to welfare: the French Case', in N. Gilbert and R.VanVoorhis (eds) Activating the unemployed:A comparative appraisal of work-oriented policies, Rutgers, NJ: Transaction Publishers: 135-83.

Barbier, J.-C. and Théret, B. (2004) Le nouveau système français de protection sociale, Paris: La Découverte.

Bec, C. (1998) L'assistance en démocratie: La politique assistancielle dans la France des XIXème et XXème siècles, Paris: Belin.

Begg, I.G. and Berghman, J. (2002) 'Introduction: EU social (exclusion) policy revisited?', Journal of European Social Policy, vol 12, no 3: 179-94.

Béland, D. (2005) 'Ideas and social policy: an institutionalist perspective', Social Policy and Administration, vol 39, no 1:1-18.

Béland, D. and Hansen, R. (2000) 'Reforming the French welfare state: solidarity, social exclusion and the three crises of citizenship', West European Politics, vol 23, no 1: 47-64.

Benn, M. (2000) 'New Labour and social exclusion', Political Quarterly, vol 71, no 3: 309-18.

Blair, T. (1999) Tony Blair's keynote speech, NCVO Annual Conference, London, 21 January (http://tinylink.com/?nYuFOEpGh5).

Blanc, M. (1998) 'Social integration and exclusion in France: some introductory remarks from a social transaction perspective', Housing Studies, vol 13, no 6:78192.

Blyth, M. (2001) 'The transformation of the Swedish model: economic ideas, distributional conflict and institutional change', World Politics, vol 54, no 1:1-26.

Blyth, M. (2002) Great transformations: Economic ideas and institutional change in the twentieth century, Cambridge: Cambridge University Press. 
Bonoli, G.(2000) The politics of pension reform: Institutions and policy change in western Europe, Cambridge: Cambridge University Press.

Bourgeois, L. (1998) [1912] Solidarité,Villeneuve d'Ascq: Presses Universitaires du Septentrion.

Campbell, J. L. (1998) 'Institutional analysis and the role of ideas in political economy', Theory and Society, vol 27, no 3:377-409.

Castel, R. (2003) [1995]From manual workers to wage laborers: Transformation of the social question, New Brunswick: Transaction Publishers.

Chirac, J. (1995) Discours de M. Jacques CHIRAC, Président de la République, à l'Assemblée des Présidents de Conseil généraux (Tours), 17 October (http:// tinylink.com/?d3s1OIL8WJ).

Clasen, J. and Clegg, D. (2003) 'Unemployment protection and labour market reform in France and Britain in the 1990s: solidarity versus activation?', Journal of Social Policy, vol 32, no 3: 361-81.

Cox, R. H. (1998) 'The consequences of welfare reform: how conceptions of social rights are changing', Journal of Social Policy, vol 26, no 1: 1-16.

Cox, R. H. (2001) 'The social construction of an imperative: why welfare reform happened in Denmark and the Netherlands but not in Germany', World Politics, vol 53, no 3: 463-98.

Daguerre,A. (2004) 'Importing workfare: policy transfer of social and labour market policies from the USA to Britain under New Labour', Social Policy and Administration, vol 38, no 1: 41-56.

Davies, J. S. (2005) 'The social exclusion debate: strategies, controversies and dilemmas', Policy Studies, vol 26, no 1:3-27.

DRESS [French Government] (2002) Les contrats d'insertion du RMI: Pratiques des institutions et perceptions des bénéficiaires (Études et résultats no 193), Paris: DRESS.

DRESS (2005) Les prestations de protection sociale en 2004 (Études et résultats no 426), Paris: DRESS.

Dwyer, P. (2004) 'Creeping conditionality in the UK: from welfare rights to conditional entitlements?', Canadian Journal of Sociology, vol 28, no 2: 261-83.

Fernández de la Hoz, P. (2001) Families and social exclusion in the European Union: Theoretical aspects, lines of convergence and unsettled issues - abridged version (Report commissioned by the European Observatory on the Social Situation, Demography and Family),Vienna: Österreichisches Institut für Familienforschung.

Fischer, F. (2003) Reframing public policy: Discursive politics and deliberative practices, Oxford: Oxford University Press.

French Government (2005) 'Vos droits et démarches: santé' (http://vosdroits.servicepublic.fr/particuliers/F2971.xhtml).

Frétigné, C. (1999) Sociologie de l'exclusion, Paris: L'Harmattan.

Friot, B. (1998) Puissances du salariat: Emploi et protection sociale à la française, Paris: La Dispute.

Furet, F., Julliard, J. and Rosanvallon, P. (1988) La république du centre, Paris: Calmann-Lévy.

Gallie, D., Paugam, S. and Jacobs, S. (2003) 'Unemployment, poverty and social isolation: is there a vicious circle of social exclusion?', European Societies, vol 5, no 1: 1-31.

Giddens, A. (2001) The third way and its critics, Cambridge: Polity Press. 
Gilbert, N. (2002) Transformation of the welfare state: The silent surrender of public responsibility, Oxford: Oxford University Press.

Goguel d'Allondans, A. (2003) L'exclusion sociale: Les métamorphoses d'un concept (1960-2000), Paris: L'Harmattan.

Hall, P. A. (1993) 'Policy paradigms, social learning and the state: the case of economic policymaking in Britain', Comparative Politics, vol 25, no 3: 275-96.

Hansen, R. and King, D. (2001) 'Eugenic ideas, political interests, and policy variance: immigration and sterilization policy in Britain and the US', World Politics, vol 53, no 2: 237-63.

Hefferman, R. (2000) New Labour and Thatcherism, Houndsmills: Macmillan.

Hills, J. (2004) Inequality and the state, Oxford: Oxford University Press.

Humphreys, J. M. (1999) 'Durkheimian sociology and 20th-century politics: the case of Célestin Bouglé, History of the Human Sciences, vol 12, no 3: 117-38.

Jenson, J. and Saint-Martin, D. (2006) 'Building blocks for a new social architecture: The LEGO ${ }^{\mathrm{TM}}$ paradigm of an active society', Policy \& Politics, vol 34, no 3: 429-51.

Jobert, B. (1994) (ed) Le tournant néo-libéral en Europe, Paris: L'Harmattan.

Jospin, L. (1998) Discours de Lionel Jospin lors de la Journée parlementaire du groupe socialiste (Tours), 29 September (http://tinylink.com/?p9V51RiD19).

King, D. (1999) In the name of liberalism: Illiberal social policy in the United States and Britain, Oxford: Oxford University Press.

Klanfer,J. (1965) L'Exclusion sociale: Étude de la marginalité dans les sociétés occidentales, Paris: Bureau de Recherches sociales.

Lenoir, R. (1974) Les exclus: Un Français sur dix, Paris: Le Seuil.

Levitas, R. (2005) [1999] Inclusive society? Social exclusion and New Labour (second edition), London: Palgrave.

Levy, J. D. (1999) 'Vice into virtue? Progressive politics and welfare reform in continental Europe', Politics \& Society, vol 27, no 2: 239-73.

Marsh, A. (2004) 'Housing and the social exclusion agenda in England', Australian Journal of Social Issues, vol 39, no 1: 7-23.

Morel, S. (2000) Les logiques de la réciprocité: Les transformations de la relation d'assistance aux États-Unis et en France, Paris: Presses Universitaires de France.

Palier, B. (2002) Gouverner la sécurité sociale, Paris: Presses Universitaires de France.

Paugam, S. (1991) La disqualification sociale: Essai sur la nouvelle pauvreté, Paris: Presses universitaires de France.

Paugam, S. (ed) (1996) L'exclusion: L'état des savoirs, Paris: La Découverte.

Prasad, M. (2005) 'Why is France so French? Culture, institutions, and neoliberalism, 1974-1981', American Journal of Sociology, vol 111, no 2: 357-407.

Ridet, P. (2006) 'Les jeunes font grise mine à Nicolas Sarkozy', Le Monde, 12 January.

Rosanvallon, P. (2000) [1995] The new social question: Rethinking the welfare state, Princeton, NJ: Princeton University Press.

Schmidt, V. A. (1996) From state to market? The transformation of French business and government, Cambridge: Cambridge University Press.

Schmidt,V.A. (2001) 'The politics of economic adjustment in France and Britain: when does discourse matter?', Journal of European Public Policy, vol 8, no 2: 24764.

Schmidt,V.A. (2002) The futures of European capitalism, Oxford: Oxford University Press. 
Schnapper, D. (1998) Community of citizens: On the modern idea of nationality, New Brunswick: Transaction Publishers.

Silver, H. (1994) 'Social exclusion and social solidarity: three paradigms', International Labour Review, vol 133, no 5-6: 531-78.

Silver, H. and Miller, S. M. (2003) 'Social exclusion: the European approach to socialdisadvantage', Indicators, vol 2, no 2: 1-17.

Somers, M. and Block, F. (2005) 'From poverty to perversity: ideas, markets, and institutions over 200 years of welfare debate', American Sociological Review, vol 70, no 2: $260-87$.

van Berkel, R. and Hornemann Møller, I. (2002) Active social policies in the EU: Inclusion through participation?, Bristol: The Policy Press.

Daniel Béland, Department of Sociology, University of Calgary, Alberta, Canada www.danielbeland.org 